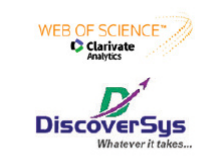

Published by DiscoverSys

\section{The effect of vitamin 25-(OH)-D3 on Glucocorticoid Receptor- $\beta$ (GR $\beta$ ) and 25-(OH)-D receptors in idiopathic nephrotic syndrome patients}

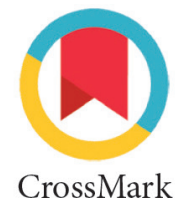

\author{
Krisni Subandiyah ${ }^{1}$, Harinda Khanifa Khusna ${ }^{1 *}$
}

\section{ABSTRACT}

Backgound: Idiopathic Nephrotic Syndrome (INS) is the most chronic glomerular disease in children. Glucocorticoid is the main therapy acts by binding to glucocorticoid receptor a (GRa), whereas it is reported that glucocorticoid receptor $\beta$ (GRB) is a main inhibitor of GRa. The interaction between glucocorticoid receptors and vitamin $D$ can increase anti-inflammation at glucocorticoid receptors, thereby decreasing GRß levels. This study was aimed to investigate the effect ssupplementation of vitamin D3 on GRß and 25-(OH)-D level in children with INS and the correlation between both of parameters.

Method: A randomized clinical trial, double blind, pre and posttest control group was conducted among 30 subjects with newly diagnosed as INS. Subjects were divided into 2 groups, group 1 (G1) were treated with prednisone and vitamin D3 whereas group 2 (G2) were only treated with prednisone. The level of GRß and 25-(OH)-D level was measured by ELISA method. Data were analyzed using SPSS version 17 for Windows.

Result: There was significant elevation of $25-(\mathrm{OH})-\mathrm{D}$ plasma between $\mathrm{G} 1(31.46 \pm 9.69 \mathrm{ng} / \mathrm{mL})$ and $\mathrm{G} 2(13.43 \pm 17.25 \mathrm{ng} / \mathrm{mL})$ $(p<0.001)$, and significant decrease of GR levels between $G 1$ $(-13.71 \pm 8.06 \mathrm{ng} / \mathrm{mL})$ and $\mathrm{G} 2(-0.917 \pm 3.76 \mathrm{ng} / \mathrm{mL})(p<0.000)$. Pearson testing first group showed that vitamin $D$ level was positively correlated with GR $\beta$ levels $(r=0.458 ; p=0.01)$.

Conclusion: The effect supplementation of vitamin D3 can increase 25-(OH)-D level and decrease of GR $\beta$ levels significantly in children with idiopathic nephrotic syndrome who receive glucocorticoid therapy.
'Department of Child Health, Faculty of Medicine, Universitas Brawijaya, Saiful Anwar General Hospital, Malang, Indonesia
*Corresponding: Harinda Khanifa Khusna Department of Child Health, Faculty of Medicine, Universitas Brawijaya, Saiful Anwar General Hospital, Malang, Indonesia dr.harinda@gmail.com
Received: 2020-02-23 Accepted: 2020-04-22 Published:2020-05-07

\section{INTRODUCTION}

Nephrotic syndrome (SN) is a chronic disease that frequently found in children. ${ }^{1}$ The incidence of $\mathrm{SN}$ in children is 2-7 new cases per 100.000 children. This disease commonly found in young children with a peak age of 2 to 5 years, and predominantly in male gender (male: female $=2: 1$ ). ${ }^{2}$ The pathogenesis of idiopathic nephrotic syndrome in children remains unclear, but several hypotheses mention it is due to T-cell dysfunction. ${ }^{3}$

Glucocorticoids has chosen as first drug therapy in nephrotic syndrome and has function as transcription factors. There are two splicing variants of glucocorticoid receptors, namely glucocorticoid receptor- $\alpha(\mathrm{GR} \alpha)$ and glucocorticoid receptors- $\beta$ $(\mathrm{GR} \beta)^{4,5}$ Glucocorticoid receptor- $\alpha(\mathrm{GR} \alpha)$ is a classic receptor which triggering the transactivation process. Meanwhile, the glucocorticoid receptor- $\beta$ $(\mathrm{GR} \beta)$ does not bind to glucocorticoids but inhibit the GR $\alpha$. The ability of GR $\beta$ to inhibit the action of GRa is thought to have a role in regulating the sensitivity of target cells to glucocorticoids. ${ }^{6}$
Vitamin $\mathrm{D}$ is a fat-soluble vitamin consisting of steroid molecules. Cholecalciferol (D3) and cholecalciferol (D2) are two form of vitamin D. In $\mathrm{SN}$, activation of vitamin $\mathrm{D}$ receptors (VDR) has a protective effect on podocytes, has limited the activation of renin-angiotensin-aldosterone system, and has an antiproteinuric effect.?

Recent studies reveal that the interaction of glucocorticoid receptors and secosteroids hormone receptor (vitamin D hormone) can be affecting glucocorticoid receptors by increasing anti-inflammatory properties of glucocorticoid receptors, thereby reducing GR $\beta$ levels. GR $\beta$ levels was decrease after vitamin D supplementation to children with low vitamin D levels who was suffering asthma. ${ }^{8}$

Thus far, no research has been reported that evaluates the relationship between supplementation of Vitamin D3 and GR $\beta$ levels in children with idiopathic nephrotic syndrome. Therefore, it will be investigated about the effect of giving vitamin D3 supplementation on levels of glucocorticoid 
receptors $\beta$ (GR $\beta)$ in idiopathic nephrotic syndrome.

\section{METHOD}

\section{Research Design}

An experimental research with double-blind randomized clinical trial (RCT) study design (pre and post-test control group) was done to answer the question study. The study group consisted of two groups: group 1 (G1) was new Idiopathic Nephrotic Syndrome patients who were given oral prednisone and vitamin D3, and group 2 (G2) was new Idiopathic Nephrotic Syndrome patients who were given prednisone alone. Both Vitamin D3 and GR $\beta$ levels were measured before and after administration of therapy. Group 1 used prednisone $2 \mathrm{mg} / \mathrm{kg} /$ day (maximum dose $80 \mathrm{mg} /$ day) and oral vitamin D3 (D-Vit, PT Gracia Pharmindo TM) $2000 \mathrm{IU} /$ day for four weeks, while group 2 used prednisone $2 \mathrm{mg} / \mathrm{kg}$ /day (maximum dose of $80 \mathrm{mg}$ / day) for four weeks.

A total of 30 subjects participated in this study (15 subjects were G1, and 15 subjects were G2). Subjects were diagnosed with new case of idiopathic nephrotic syndrome who underwent outpatient care at the Children's Nephrology Clinic or were hospitalized in the children's ward RSSA Malang on August 2016 - August 2017. The inclusion criteria were subjects with new idiopathic nephrotic syndrome diagnosis, aged between 1 to 18 years, and the patient's parents allowed their children to be included in the study after being explained (informed consent). Exclusion criteria were secondary nephrotic syndrome patients, nephrotic syndrome patients less than one year old/infantile nephrotic syndrome, relapsed nephrotic syndrome patients and steroid-dependent nephrotic syndrome patients. Drop-out criteria are patients who do not take prednisone or vitamin D3 supplementation recommended by the researcher, and parents or children want to stop following the study.

Blood samples taken from venous blood are collected in centrifuge tubes. The sample was centrifuged for 20 minutes at speed 1000 times of gravitation (1000G). Then, the plasma was transferred to be checked of $25(\mathrm{OH})$ D levels and beta glucocorticoid receptors.

Examination procedure was accordance to ELISA Kit (Alegria Human Vitamin D Kit catalogue number ORG 270). Predilution sample serum $(200 \mu \mathrm{l})$ was added to each well and incubated for 2 hours at $25^{\circ} \mathrm{C}$ then wash. After washing procedure, $100 \mu \mathrm{l}$ of the enzyme conjugate was added and incubated for 30 minutes at room temperature. Then, $100 \mathrm{ml}$ of chromogen/substrate was added and incubated for 15 minutes at room temperature without being shaken and protected from direct sunlight. Finally, $100 \mu \mathrm{l}$ of stopping solution was added to each well. The blue colour's of the absorbance intensity was read at $650 \mathrm{~nm}$ spectrophotometrically. Vitamin D levels are categorized as deficiency if serum $25(\mathrm{OH})$ D levels $>20 \mathrm{ng} / \mathrm{ml}$, insufficiency if $10-20 \mathrm{ng} / \mathrm{ml}$ and deficiency if $<10 \mathrm{ng} / \mathrm{ml}$.

The reagents were prepared according to the procedure from the kit manufacturer (Mybiosource Cat \# MBS039666).). A total of $50 \mu \mathrm{L}$ assay diluents were put into each well. Then $200 \mu \mathrm{L}$ of the standard solution or sample examined is added. Then the plates were covered and incubated for 3 hours at room temperature. Then the washing process was performed, the liquid in the well was discharged, the remaining liquid was dried by turning and pressing the surface of the plate on tissue paper. A total of $400 \mu \mathrm{L}$ of washing buffer solution was put into the well and then removed. This washing procedure was carried out 3 times. Two hundred $\mu \mathrm{L}$ glucocorticoid conjugates $\beta$ were added to each well, then covered and incubated for 2.5 hours at room temperature. After that, the washing process was carried out again. A total of $50 \mu \mathrm{L}$ substrate was added, then covered and incubated for 1 hour at room temperature. Then $50 \mu \mathrm{L}$ stop solution was added. Optical density (OD) must be measured within 30 minutes using a microplate reader (Biorad 520 with a wavelength of $450 \mathrm{nM}$ ).

The normality of sample data was tested using the Kolmogorov-Smirnov test. The decision criteria are if the $p$-value was greater than 0.05 , then the data is normally distributed. Differences in GR $\beta$ levels, plasma vitamin $25(\mathrm{OH})$ D levels were performed by independent T-tests. The relationship of GR $\beta$ levels with plasma vitamin $25(\mathrm{OH})$ D levels was performed by Pearson correlation test. Data were analyzed using $95 \%$ confidence level $(\alpha=0.05)$. All calculations were done with SPSS for Windows 17.

\section{RESULT}

During fourt weeks observation and treatment period, no subjects were found to be sick or affected by side effects due to the use of prednisone or vitamin D3. The subject's essential characteristics such as age, sex, vitamin D status and nutritional status are shown in Table 1. Clinical outcomes in the subjects appear in Table 2, which shows that in G1, more patients experienced remission before four weeks of therapy (13/30) compared to G2 (6/30).

The comparative test result levels of $25(\mathrm{OH})$ $\mathrm{D}$ explained that there were significant differences in plasma vitamin $25(\mathrm{OH}) \mathrm{D}$ levels between the treatment groups of prednisone + vitamin D3 exposure $(31.46 \pm 9.69 \mathrm{ng} / \mathrm{mL})$ and the group of 
prednisone only exposure $(13,43 \pm 17.25 \mathrm{ng} / \mathrm{mL})$ $(\mathrm{p}=0.001<\propto)($ Table 3$)$.

The comparative tests result of glucocorticoid receptor levels of $\beta$ explain the significant difference in GR $\beta$ levels between the treatment groups of prednisone + vitamin D3 exposure (-13.71 \pm 8.06 $\mathrm{ng} / \mathrm{mL}$ ) and the group of prednisone only exposure

Table 1. Characteristics of Research Subjects

\begin{tabular}{ccc}
\hline Subjects Characteristics & $\begin{array}{c}\text { Prednisone+ } \\
\text { Vitamin D3 } \\
(\mathbf{n}=\mathbf{1 5})\end{array}$ & $\begin{array}{c}\text { Prednisone } \\
(\mathbf{n = 1 5 )}\end{array}$ \\
\hline Age(year): & $9(60.0)$ & $7(46.7)$ \\
$1-\leq 5$ year & $6(40.0)$ & $5(33.3)$ \\
$>5-<10$ year & $0(0.0)$ & $3(20.0)$ \\
$\geq 10-14$ year & $12(80.0)$ & $11(73.3)$ \\
Sex: & $3(20.0)$ & $4(26.7)$ \\
$\quad$ Male & & $8(53.3)$ \\
Female & $1(6.7)$ & $7(46.7)$ \\
Vitamin D Status: & $12(80.0)$ & $0(0.0)$ \\
Normal & $2(13.3)$ & $13(86.7)$ \\
Insufficiency & & $2(13.3)$ \\
$\quad$ deficiency & $13(86.7)$ &
\end{tabular}

Table 2. Clinical Outcomes of Study Subjects

\begin{tabular}{lcc}
\hline \multicolumn{1}{c}{ Clinical Outcomes } & $\begin{array}{c}\text { Prednisone+ } \\
\text { Vitamin D3 } \\
(\mathbf{n = 1 5 )}\end{array}$ & $\begin{array}{c}\text { Prednisone } \\
(\mathbf{n}=\mathbf{1 5})\end{array}$ \\
\hline Classification: & $15(100.0)$ & $13(86.7)$ \\
SNSS & $0(0.0)$ & $2(13.3)$ \\
SNRS & & \\
\hline Remisi: & $13(86.7)$ & $6(40.0)$ \\
Early responder & $2(13.3)$ & $7(46.7)$ \\
Late responder & $0(0.0)$ & $2(13.3)$ \\
No remission & & \\
\hline
\end{tabular}

Table 3. Comparative Tests Result of Vitamin D Levels

\begin{tabular}{llccc}
\hline \multirow{2}{*}{ Variable } & Group & \multicolumn{2}{c}{ Treatment } & \multirow{2}{*}{\begin{tabular}{c} 
p-value \\
(indepen \\
\cline { 3 - 4 }
\end{tabular}} \\
\cline { 3 - 4 } & & Pred+vit D & Prednisone & \\
\cline { 3 - 4 } & Pre test & $14.87 \pm 7.47$ & $27.25 \pm 14.99$ & 0.008 \\
\hline \multirow{2}{*}{$\begin{array}{l}25(\mathrm{OH}) \mathrm{D} \\
\mathrm{ng} / \mathrm{mL}\end{array}$} & Post test & $46.34 \pm 14.19$ & $40.66 \pm 13.96$ & 0.281 \\
& Difference & $31.46 \pm 9.69$ & $13.43 \pm 17.25$ & 0.001 \\
\hline
\end{tabular}

$(-0.9173 \pm 3.76 \mathrm{ng} / \mathrm{mL})(\mathrm{p}=0,000<\propto)($ Table 4$)$.

The correlation test results showed that there was a significant relationship or correlation between decreased GR $\beta$ levels with increased plasma vitamin $25(\mathrm{OH})$ D levels $(r=-0,458 ; \mathrm{p}=0.01)$ in pediatric patients diagnosed with idiopathic nephrotic syndrome with exposure to prednisone + vitamin D3 (Table 5).

\section{DISCUSSION}

The most distribution is obtained at the age of fewer than ten years (27 subjects). This is consistent with previous epidemiological data that $75 \%$ of SNI's are less than 10 years old. ${ }^{2}$ Gender is found that male dominant than female. Comparison of male-dominated incidents with a 2: 1 ratio. The Higher prevalence in boys is thought to be related to abnormal T-cell clones that often occur in boys' thymus glands. ${ }^{2}$

The results of clinical examination of nutritional status are mostly in good nutritional condition, but children with SNI are very at risk of experiencing growth disorders so that nutritional evaluation must be carried out regularly. ${ }^{2}$ The results of this study found 21 out of 30 SNI subjects had low vitamin D levels, similar to research in Jakarta which reported that 22 of the 26 SNI subjects had low vitamin D levels. In SN, where leakage of albumin filtration occurs in the glomerulus, DBG (vitamin D-binding globulin) leakage also occurs, which has a smaller molecular weight than albumin. This leakage results in a decrease of $25(\mathrm{OH}) \mathrm{D}$ concentration in circulation. In a study by Nielsen et al., ${ }^{9}$ It was found that $93 \%$ of children with SN had vitamin D deficiency at the start of diagnosis and $25(\mathrm{OH})$ $\mathrm{D}$ levels were positively correlated with plasma albumin. Thus, vitamin $\mathrm{D}$ has been shown to be important in the pathogenesis of autoimmune diseases such as $\mathrm{SN} .{ }^{10}$

A significant difference was found in the difference average in levels of $25(\mathrm{OH}) \mathrm{D}$ plasma in G1 (31.46 $\pm 9.69 \mathrm{ng} / \mathrm{mL})$ and G2 (13.43 \pm 17.25 $\mathrm{ng} / \mathrm{mL})(\mathrm{p}=0.001)$. Vitamin D3 that given as adjuvant therapy in this study will then be absorbed in the intestine and then transported into the blood through vitamin D binding protein (DBP). In the liver, hydroxylated vitamin $\mathrm{D}$ results in the formation of 25-hydroxyvitamin D3 (25 (OH) D) which is the most common form of vitamin $\mathrm{D}$ in plasma. So this explains that the administration of vitamin D therapy can increase levels of $25(\mathrm{OH}) \mathrm{D}$ in plasma.

In this study, a significant difference result was found in the GR $\beta$ levels $(\mathrm{p}=0,000)$ between $\mathrm{G} 1$ $(-13.71 \pm 8.06)$ and to G2 $(-0.917 \pm 3.76)$. This result shows that the administration of prednisone plus 
Table 4. Comparative Test Results of GR $\beta$ Levels

\begin{tabular}{|c|c|c|c|c|}
\hline \multirow{3}{*}{ Variable } & \multirow{3}{*}{ Group } & \multicolumn{2}{|c|}{ Treatment } & \multirow{3}{*}{$\begin{array}{c}p \text {-value } \\
\text { (independent) }\end{array}$} \\
\hline & & Pred+vit D & Prednisone & \\
\hline & & average \pm SD & average $\pm S D$ & \\
\hline \multirow{3}{*}{$\begin{array}{l}\mathrm{GR} \beta \\
(\mathrm{ng} / \mathrm{ml})\end{array}$} & Pre & $19.47 \pm 9.04$ & $13.01 \pm 11.19$ & 0.094 \\
\hline & Post & $5.75 \pm 5.12$ & $12.10 \pm 9.34$ & 0.029 \\
\hline & difference & $-13.71 \pm 8.06$ & $-0.9173 \pm 3.76$ & 0.000 \\
\hline
\end{tabular}

Table 5. Correlation Test Results

Correlation Variable $\quad$ n $\underset{(r)}{\text { coefficient }} p$-value

Decreased in GR $\beta$ levels with increased Vit D levels $\quad 30 \quad-0,458 \quad 0,01$

vitamin D3 can reduce GR $\beta$ levels compared to those given prednisone alone.

Glucocorticoid receptors $\beta$ are thought to be responsible for the emergence of certain tissue insensitivity to glucocorticoids, namely in some diseases due to impaired immune function regulation. Among others are glucocorticoid resistant asthma, SLE, rheumatoid arthritis and chronic lymphoblastic leukaemia. ${ }^{4}$ Increased numbers of proinflammatory cytokines such as IL-1, IL-2, IL-4, IL-7, IL-8, IL-18, TNFa and interferon $\alpha$ and $g$ are thought to be responsible for increasing GR $\beta$ expression in patients with the above abnormalities. ${ }^{4}$

It was reported that GR $\beta$ had a dominantnegative effect on GRa action. Some mechanisms that might explain the dominant-negative function of GR $\beta$ include competition in GRE bonds where between GR $\alpha$ and GR $\beta$ share DBD, the formation of GR $\alpha-G R \beta$ heterodimers that activate transcription, and/or decrease the co-activators needed by GRa for activation of transcription of anti-inflammatory genes. The ability of GR $\beta$ to inhibit the action of GRa is thought to have a role in regulating the sensitivity of target cells to glucocorticoids. ${ }^{6}$

A significant positive relationship between decreased GR $\beta$ levels with increased plasma vitamin $25(\mathrm{OH}) \mathrm{D}$ was obtained in this study ( $\mathrm{r}$ $=-0,458 ; \mathrm{P}=0.01)$. Steroid hormone receptors and vitamin $\mathrm{D}$ receptors are members of nuclear receptors with homologous structures that are very ease for interactions between these molecules to affect resistance and sensitivity to glucocorticoids. ${ }^{11}$
Vitamin D in its active form (calcitriol) interacts with VDR (vitamin D receptor). In the cytoplasm, vitamin D3 binds to its receptors and forms a heterodimer with a retinoid X-receptor (RXR), which in turn translocate to the nucleus. In the nucleus, the VDR-RXR complex will bind to VDRE. This bond will then attract co-activators and enzymes through histone acetylation activity, causing structural changes in chromatin that will trigger gene transcription. ${ }^{12,13}$

Various studies have shown that vitamin D can increase the action of glucocorticoids by increasing the anti-inflammatory activity of glucocorticoids. In research, vitamin $D$ has been shown to increase the expression of MKP-1 mRNA by cells through an increase in GR binding to MKP-1 promoters resulting in an increase in transcription of IL-10 and MKP-1 anti-inflammatory protein genes (mitogenactivated protein kinase phosphatase- 1) mediated by glucocorticoid bonds with GR. Induction of IL10 and MKP-1 production is known to increase the anti-inflammatory function of glucocorticoids and increase cell sensitivity to glucocorticoids..$^{14,15,16}$

\section{RESEARCH LIMITATIONS}

Vitamin D3 supplementation was not distinguished between subjects with normal plasma vitamin 25 (OH) D levels, insufficiency or deficiency, factors affecting changes in vitamin D levels such as high nutrient intake of vitamin D such as milk, or levels of exposure to sunlight, settlement which is inhabited by patients can also be a confounding factor so that it can affect the results of the study, other biomolecular factors that have not been studied in this study include levels of glucocorticoid receptors $\alpha(G R \alpha)$ and vitamin D receptors (VDR).

\section{CONCLUSION}

Supplementation of vitamin D3 can increase levels of $25(\mathrm{OH})$ D and reduce levels of GR $\beta$ in SNI children receiving corticosteroid therapy.

\section{CONFLICT OF INTEREST}

The authors confirm there are no conflict of interest during study procedure and publish procedure

\section{FUNDING}

This research was funded privately by authors

\section{ETHICAL CLEAREANCE}

This research was conducted after obtaining approval from the ethics commission RSAA Malang Research. 


\section{AUTHOR CONTRIBUTION}

All authors contributed to the process of this research

\section{REFERENCES}

1. Bagga, A, Sinha, A, 2012, Nephrotic syndrome, Symposium on Pediatic Nephrology, Indian Jornal of Pediatrics, vol.79, no.8,hh. 1045-1055.

2. Eddy, A, \& Symons, M, 2003, Nephrotic syndrome in childhood, Lancet, vol. 362, hh.629- 639.

3. Zachwieja J., Bobkowski W., Zachweija A.D., Stachowiak M.L., Zaniew M., Maciejewski J, 2012, Intracellular cytokines of peripheral blood limphocytes in nephrotic syndrome, Pediatric Nephrology, vol.17,hh 733-740.

4. Kino T., Manoli I., Kelkar S., Wang Y., Su Y.A., \& Chrousos G.P, 2009, Glucocorticoid receptor (GR) $\beta$ has intrinsic, GRa-independent transcriptional activity, Biochemical and Biophysical Research Communications, vol.381, hh.671675.

5. UKK Nefrologi IDAI, 2008, Konsensus tata laksana sindrom nefrotik idiopatik pada anak, Trihono P.P., Alatas H., Tambunan T., Pardede S.O. (Penyunting), Badan Penerbit Ikatan Dokter Anak Indonesia Jakarta, Edisi ke-2.

6. Charmandari E., George P. C., Ichijo T., Bhattacharyya N., Vottero A., Souvatzoglou E., and Kino T, 2009, The human glucocorticoid receptor (hGR) $\beta$ isoform suppresses the transcriptional activity of hGRa by interfering with formation of active coactivator complexes. Molecular Endocrinology,vol.19, no.1, hh.52-64.

7. Cheng, X., Zhao X., Khurana S., Bruggeman L., 2013 Microarray Analyses of Glucocorticoid and Vitamin D3 Target Genes in Differentiating Cultured Human Podocytes, PLoS One, vol.8, no. 4

8. Kalra N., \& Ishmael F, 2014, Cross-talk between vitamin
$\mathrm{D}$, estrogen and corticosteroids in glucocorticoid resistant asthma, OA Inflammation, vol.2, no.1, hh.2

9. Nielsen, C.A., Jensen, J.-E.B., Cortes, D., 2015. Vitamin D status is insufficient in the majority of children at diagnosis of nephrotic syndrome. Dan. Med. J. 61: 1-5

10. Hewison M, 2010, Vitamin D an the immune system : new perspective on an old theme. Endocrinology Metabolism Clinics of North America,vol. 39, hh. 365-379.

11. Teeninga, Nynke. 2013. Glucocorticoid Treatment in Childhood Nephrotic Syndrome: Weighing the Cornerstone. Netherlands: Gildeprint Drukkerijen.

12. Asariati, Husnul.,et al. , 2014, Vitamin D3 adjuvant treatment stimulate interleukin-10 expression in children with nephrotic syndrome without affecting to clinical outcome and glucocorticoid receptor expression. The Journal of Tropical Life Science, vol.4, no.3: 166-174

13. Leung D.Y.M.and Bloom J.W, 2003, Update on glucocorticoid action and resistance. Journal of Allergy and Clinical Immunology, vol.111, hh 3-22.

14. Vegiopoulos A. and Herzig S. 2007. Glucocorticoids, metabolism and metabolic diseases. Molecular and Cellular Endocrinology, vol. 275, hh. 43-61.

15. Loweberg M., Stanh C., Hommes D.W., and Buttgereit F, 2008, Novel insights into mechanisms of glucocorticoid action and the development of new glucocorticoid receptor ligands. Steroids, vol. 73, hh.1025-1029.

16. Damanik, V.I., Putra, I.B., Ginting, O. 2019. Analysis of serum 25-Hydroxyvitamin D level in keloid patients. Bali Medical Journal 8(1): 312-315. DOI:10.15562/bmj. v8i1.1360

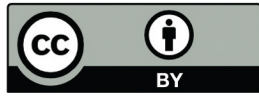

This work is licensed under a Creative Commons Attribution 